\title{
Analisis Sentimen Vaksinasi Covid-19 Pada Twitter Menggunakan Naive Bayes Classifier Dengan Feature Selection Chi-Squared Statistic Dan Particle Swarm Optimization
}

\author{
Ristasari Dwi Septiana ${ }^{1}$, Agung Budi Susanto ${ }^{2}$, Tukiyat ${ }^{3}$ \\ 1,2,3 Teknik Informatika, Pascasarjana Universitas Pamulang, Tangerang Selatan, Indonesia \\ ${ }^{1}$ ristasari.dwis@gmail.com, ${ }^{2}$ agungpsmk@gmail.com, ${ }^{3}$ dimastuky@gmail.com
}

Diterima : 31 Agustus 2021

Disetujui : 28 September 2021

\begin{abstract}
Tingginya penyebaran Covid-19 semakin berdampak pada bidang kesehatan, ekonomi, bahkan bidang pendidikan di Indonesia, sehingga pemerintah Indonesia melakukan tindakan vaksinasi Covid-19 guna menekan tingkat penyebaran Covid-19 di Indonesia. Namun hal tersebut dinilai kotroversial sehingga menarik perhatian masyarakat untuk memberikan opini di berbagai media seperti media sosial twitter. Sehingga membutuhkan analisa sentimen masyarakat terhadap upaya pemerintah pada tindakan vaksinasi Covid-19 untuk mencapai hasil prediksi dengan nilai akurasi paling optimal. Proses crawling secara otomatis menggunakan tools Rapidminer akan mengambil data tweets yang mengandung 5 (lima) kata kunci, yaitu "Vaksin Sinovac", “Vaksin Astrazeneca”, "Vaksin Moderna”, “Vaksin Merah Putih", dan "Vaksinasi Covid-19”. Dataset tweets didapatkan dari tanggal 4 Agustus 2021 sampai 12 Agustus 2021. Dataset diperoleh sejumlah 2060 tweets dan diberi label secara manual didapatkan jumlah tweet sebanyak 1193 sentimen positif, 73 negatif, dan 794 netral. Data tersebut dianalisa dengan menggunakan Metode Feature Selection Chi-Squared Statistic dan Particle Swarm Optimization (PSO) untuk mengurangi atribut yang kurang relevan pada saat proses klasifikasi dengan algoritma Naive Bayes Classifier (NBC). Hasil pengujian menunjukan bahwa Algoritma Naive Bayes Classifier (NBC) tanpa Feature Selection mendapatkan nilai akurasi 63,69\%. Hasil penelitian menunjukkan bahwa Algoritma Naive Bayes Classifier (NBC) dengan Feature Selection Chi-Squared Statistic mempunyai tingkat akurasi 69,13\%. Sedangkan hasil pengujian algoritma Naive Bayes Classifier (NBC) dengan Particle Swarm Optimization mempunyai tingkat akurasi 66,02\%. Dengan demikian hasil seleksi fitur Chi-Squared Statistic mendapatkan nilai akurasi yang lebih baik jika dibandingkan dengan Particle Swarm Optimization untuk proses klasifikasi algoritma Naive Bayes Classifier (NBC) dengan selisih akurasi 3,11\%.
\end{abstract}

Keywords-Analisis Sentimen, Chi-Squared Statistic, NBC, PSO, Twitter

\section{Pendahuluan}

Wabah covid-19 di Cina pada bulan Desember tahun 2019 merebak ke berbagai negara di dunia sehingga World Health Organization (WHO) menjadikan wabah tersebut sebagai pandemi global. Corona virus menjadi virus yang sangat berbahaya dengan tingkat penyebaran yang sangat cepat hingga meluas ke seluruh dunia termasuk Indonesia. Dampak wabah covid-19 di Indonesia selain bidang kesehatan juga berdampak pada bidang ekonomi dan pendidikan. Data WHO pada tanggal 5 Juni 2021 tercatat 173.357 .945 kasus positif covid-19, 156.121.170 kasus sembuh dan 3.728.668 kasus meninggal dunia. Sedangkan kasus covid-19 di Indonesia tercatat 1.850 .206 kasus positif, 1.701.784 kasus sembuh dan 51.449 kasus 
meninggal dunia. Banyaknya kasus covid-19 sangat berpengaruh di berbagai sektor kehidupan manusia, seperti ekonomi, pendidikan, politik, dan kehidupan sosial [1]. Upaya pemerintah Indonesia di antaranya dengan memberlakukan kebijakan protokol kesehatan, Pembatasan Sosial Berskala Besar (PSBB) hingga vaksinasi masyarakat untuk menekan penyebaran Covid19. Tindakan vaksinasi masyarakat dinilai kontroversial dengan munculnya berbagai merek vaksin sehingga banyak kalangan mengutarakan pendapatnya di berbagai media. Twitter menjadi salah satu media bagi masyarakat untuk menyampaikan pendapat mereka tentang vaksinasi covid-19 di Indonesia. Pada kwartal ketiga tahun 2019 jumlah pengguna aktif twitter tercatat meningkat $17 \%$ menuju angka 145 juta pengguna [1].

Analisis sentimen berada di antara berbagai bidang penelitian lainnya seperti Data Mining, Natural Language Processing (NLP) dan Machine Learning untuk melakukan ekstraksi sentimen terhadap sebuah isi kalimat [2]. Analisis sentimen dilakukan untuk mengelompokkan dokumen, kalimat, atau pendapat berdasarkan polaritas teks di dalamnya. Polaritas tersebut merupakan pendapat yang memiliki aspek positif, negatif atau netral [3]. Klasifikasi dengan analisis sentimen membantu memberikan masukan dan tanggapan dari pelanggan dengan cepat [4].

Naive Bayes merupakan teknik klasifikasi yang paling sering digunakan untuk klasifikasi data yang disebut dengan Naive Bayes Classifier (NBC). Pemilihan algoritma Naive Bayes ini karena sangat cocok untuk short data text dan sederhana namun memiliki nilai akurasi yang tinggi dalam pengklasifikasian data teks [5]. Metode Naïve Bayes banyak digunakan di berbagai penelitian tentang analisis dokumen tekstual dan merupakan algoritma populer karena kemudahan penggunannya serta telah terbukti memuaskan di banyak domain penelitian [6].

Salah satu faktor penting untuk meningkatkan nilai akurasi klasifikasi adalah seleksi fitur. Apabila dataset berisi fitur yang banyak, maka dimensi ruang menjadi besar dan tingkat akurasi klasifikasi menjadi rendah. Seleksi fitur digunakan untuk mengurangi jumlah set fitur yang besar menjadi subset fitur yang relatif lebih kecil agar nilai akurasi klasifikasi meningkat [4]. Seleksi fitur chi-squared statistic dan particle swarm optimization digunakan untuk mengurangi gangguan (noise) pada saat klasifikasi menggunakan teknik pembelajaran mesin Naive Bayes Clasifier. Penelitian terdahulu menunjukan bahwa frekuensi fitur dalam kategori benar dan dalam kategori palsu berperan penting dalam pemilihan fitur chi-squared [3].

Seleksi fitur diperlukan untuk mendapatkan fitur-fitur yang relevan yang selanjutnya akan digunakan dalam proses konstruksi model probabilistik NBC. Penyeleksian fitur yang digunakan adalah chi-squared dan particle swarm optimization. Penelitian ini bertujuan untuk memprediksi sentimen masyarakat terhadap tindakan vaksinasi covid-19 dengan cara mengkomparasi metode Feature Selection Chi Squared Statistic dan Particle Swarm Optimization pada algoritma Naive Bayes Classifier ke dalam sentimen positif, negatif dan netral dengan menggunakan data tweet masyarakat dari media sosial twitter. Data yang diperoleh selanjutnya dibagi menjadi data pelatihan untuk memperoleh model klasifikasi dan data pengujian yang digunakan untuk menguji hasil klasifikasi dari algoritma NBC.

Demi mendapatkan hasil penelitian yang tepat guna, peneliti merujuk beberapa penelitian terkait yang pernah dilakukan sebelumnya sebagai komparasi dan data-data penunjang dalam penelitian ini. Penelitian yang dilakukan oleh Laurensz dan Sediyono dengan Metode Nä̈ve Bayes dan Support Vector Machine (SVM) untuk menganalisis sentimen masyarakat terhadap tindakan vaksinasi dalam upaya mengatasi pandemi covid-19 [7]. Klasifikasi metode Nä̈ve Bayes mendapatkan rata-rata akurasi $85,59 \%$, sedangkan SVM sebesar $84,41 \%$. Penelitian yang dilakukan Naraswati dengan Metode Naive Bayes Classification tentang Analisis Sentimen Publik dari Twitter tentang Kebijakan Penanganan Covid-19 di Indonesia [8]. Nilai akurasi klasifikasi yang didapatkan sebesar 87,34\%, 
dengan sensitivitas sebesar 93,43\%, dan spesifisitas $71,76 \%$. Penelitian yang dilakukan Yono Cahyono menggunakan $N B C$ dengan Feature Selection PSO dan Term Frequency untuk menganalisis sentiment masyarakat pada sosial media twitter terhadap layanan Telkom Indihome [4]. Hasil pengujian seleksi fitur Particle Swarm Optimization (PSO) terbukti dapat meningkatkan akurasi algoritma Naïve Bayes Classifier sebesar 97,48\%.

\section{Metodologi Penelitian}

Metode yang digunakan dalam penelitian ini meliputi tiga proses utama yaitu preprocessing, pelatihan dan pengujian.

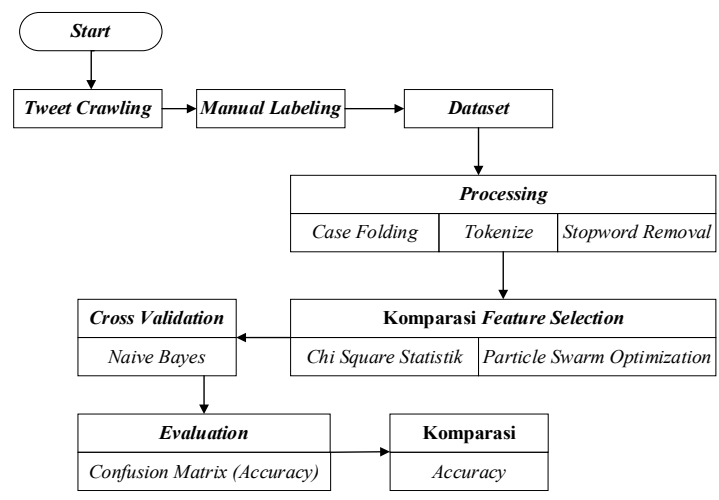

Gambar 1. Metodologi Penelitian

\subsection{Preprocessing}

Tweet crawling adalah tahapan yang dilakukan untuk mendapatkan data tweet masyarakat tentang vaksinasi covid-19 dari media sosial twitter. Sebelum menjadi dataset terlebih dahulu dilakukan tahapan manual labelling, yaitu memberikan label terhadap kalimat tweet tersebut kedalam kategori positif, netral atau negatif secara manual. Preprocessing adalah tahap yang dilakukan sebelum proses pelatihan pada algoritma NBC dan tahapan yang penting bagi dataset pada proses mining. Preprocessing dilakukan untuk menghindari dataset yang kurang sempurna, terdapat noise pada dataset, data-data yang tidak konsisten dan mempercepat pemrosesan terhadap dokumen [6]. Proses-proses yang dilakukan preprocessing yaitu case folding, tokenize, dan stopwords removal.

\section{a. Case Folding}

Tahap ini merupakan proses untuk mengubah semua huruf pada dokumen menjadi huruf kecil. Hanya huruf 'a' sampai dengan ' $z$ ' saja yang diterima. Karakter yang di anggap sebagai delimeter seperti titik (.), koma (,), spasi dan karakter angka pada dokumen akan dihilangkan. Berikut adalah flowchart tahap case folding.

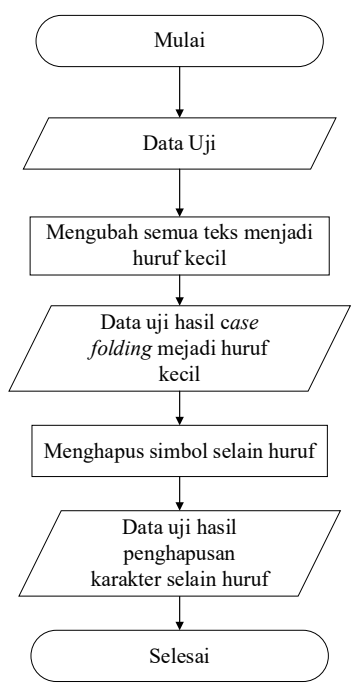

Gambar 2. Flowchart Tahapan Case Folding

\section{b. Tokenize}

Tahap memotong string input berdasarkan kata yang menyusunnya serta membedakan karakter-karakter tertentu yang diperlukan sebagai pemisah kata atau bukan. Tahap ini dilakukan setelah melewati tahap case folding. Berikut adalah flowchart tahap tokenizing.

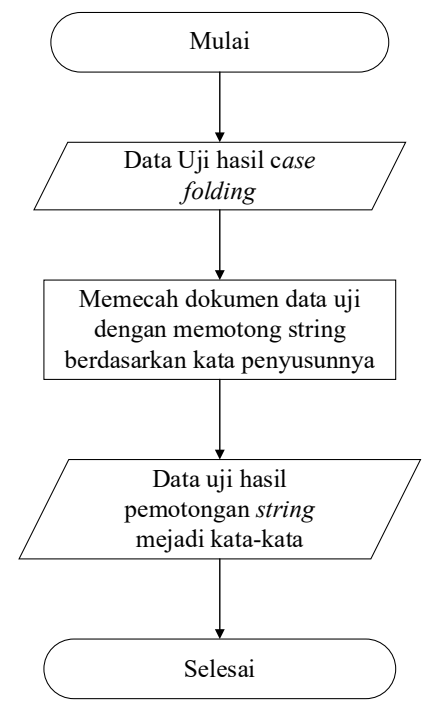

Gambar 3. Flowchart Tahapan Tokenize 


\section{c. Stopwords Removal}

Tahap menghilangkan kata-kata yang tidak memiliki arti, berdasarkan daftar stopwords bahasa Indonesia sebanyak 758 kata. Berikut adalah flowchart tahap stopwords.

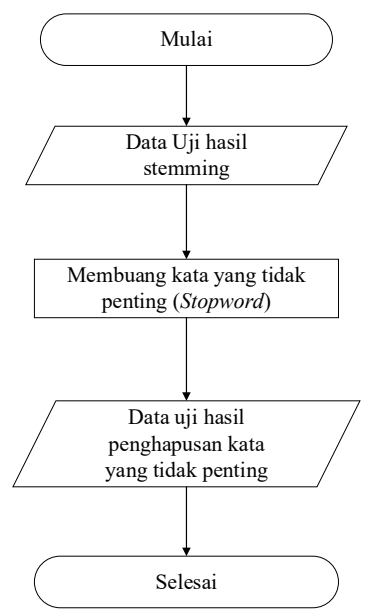

Gambar 4. Flowchart Tahapan Stopwords

\subsection{Pelatihan}

\section{a. Seleksi Fitur Chi-Squared Statistic}

Nilai seleksi fitur Chi-Squared Statistic diperoleh dengan menggunakan persamaan (1).

$$
X^{2}(t, c)=\frac{N x(A D-C B)^{2}}{(A+C) \times(B+D) \times(A+B) \times(C+D)}
$$

Keterangan:

$A$ : Banyaknya dokumen dalam kategori $c$ yang mengandung term $t$

$B$ : Banyaknya dokumen yang bukan kategori $c$ tetapi mengandung term $t$

$C$ : Banyaknya dokumen dalam kategori $c$ tetapi tidak mengandung term $t$

$D$ : Banyaknya dokumen yang bukan kategori $c$ dan tidak mengandung term $t$

$N$ : Total keseluruhan dokumen

Melalui Chi-Squared Statistic kesesuaian (goodnes of fit) dari kategori terhadap terms dapat diamati [4]. Dalam statistika uji ChiSquared Statistic diterapkan untuk melihat independensi terhadap dua peristiwa. Sedangkan dalam seleksi fitur melihat kemunculan dari fitur dan kemunculan dari kategori.

\section{b. Particle Swarm Optimization (PSO)}

Particle Swarm Optimization (PSO) adalah teknik optimasi stokastik berbasis populasi yang dikembangkan oleh Eberhart dan Kennedy pada tahun 1995, yang terinspirasi oleh perilaku sosial kawanan burung atau ikan [9]. Teknik ini diawali dari populasi sejumlah term yang dibangkitkan secara acak dan selanjutnya dicari solusi optimum dengan memperbaiki term untuk sejumlah kategori tertentu. Posisi $(x i, d)$ dan kecepatan $(c i, m)$ dibangkitkan dari kumpulan partikel secara acak dengan menggunakan batas bawah $\left(\mathrm{X}_{\min }\right)$ dan batas atas $\left(\mathrm{X}_{\max }\right)$. Selanjutnya update velocity (kecepatan) semua term berdasarkan nilai fitness untuk menentukan term yang memiliki nilai global terbaik (global best) dan posisi terbaik (local best) dari setiap term pada semua waktu sekarang dan sebelumnya. Lakukan pengulangan sampai kriteria terpenuhi.

$$
\begin{aligned}
& V_{i m}=w . V_{i m}+C_{1} * R *\left(\text { pbest }_{i m}-X_{i m}\right)+C_{2} * R *\left(\text { gbest }_{m}-X_{i m}\right) \\
& \boldsymbol{x i d}=\boldsymbol{x} \boldsymbol{i}, \boldsymbol{m}+\boldsymbol{v i}, \boldsymbol{m}
\end{aligned}
$$

Dimana:

$n:$ jumlah partikel dalam kelompok

$d$ : dimensi

$v i, m:$ kecepatan partikel ke-i pada iterasi ke-i

$w$ : faktor bobot inersia

$c_{1}, c_{2}$ : konstanta akeselerasi (learning rate)

$R$ : bilangan random $(0-1)$

$X i, d$ : posisi saat ini dari partikel ke-i pada iterasi ke-i pbesti : posisi terbaik sebelumnya dari partikel ke-i gbest : partikel terbaik diantara semua partikel dalam satu kelompok atau populasi

\section{c. Nä̈ve Bayes Classifier (NBC)}

Algoritma NBC digunakan untuk mencari nilai probabilitas tertinggi untuk mengklasifikasikan data uji pada kategori yang paling tepat [10]. Klasifikasi naïve bayes juga digolongkan ke dalam pembelajaran terawasi (supervised learning) di mana untuk penentuan kelas objek uji didasarkan dari data latihnya dan setiap objek di data latih telah diketahui kelasnya masing-masing [11]. Rumus teorema bayes dapat dilihat seperti berikut ini.

$P(H \mid X)=\frac{P(X \mid H) * P(H)}{P(X)}$

Dengan:

H: hipotesisnya

$\mathrm{X}$ : kejadian yang merealisasikan ke hipotesis

$\mathrm{P}(\mathrm{H})$ : peluang hipotesis

$\mathrm{P}(\mathrm{X})$ : peluang kejadian

$\mathrm{P}(\mathrm{X} \mid \mathrm{H})$ : peluang banyak $\mathrm{X}$ di dalam $\mathrm{H}$

$\mathrm{P}(\mathrm{H} \mid \mathrm{X})$ : peluang banyaknya $\mathrm{H}$ di dalam $\mathrm{X}$ 


\subsection{Pengujian}

\section{a. Pengujian K-Fold Cross Validation}

Cross Validation merupakan metode untuk menemukan parameter terbaik dengan menguji besarnya galat pada data pengujian. Metode ini membagi dataset secara acak dengan ukuran yang sama ke dalam $k$ bagian dan tiaptiap bagian akan dilakukan proses klasifikasi [12]. Untuk pengujian yang biasa di gunakan adalah dengan $k=10$, atau 10-fold cross validation. Sebuah partisi $k$-Fold dari dataset dibuat. Setiap percobaan $k, k-1$ lipatan digunakan untuk pelatihan dan sisanya satu untuk pengujian. Maka rata-rata error $E$ di semua cobaan $k$ dihitung sebagai berikut.

$$
E=\frac{1}{k} \sum_{i=1}^{k} E_{i}
$$

\section{b. Confusion Matrix}

Proses prediksi yang dilakukan diharapkan mampu melakukan klasifikasi semua dataset dengan benar, tetapi tidak dapat dipungkiri jika kinerja suatu sistem tidak $100 \%$ benar sehingga perlu dilakukan pengukuran kinerja klasifikasi dengan menggunakan matriks konfusi (confusion matrix). Matriks konfusi merupakan tabel pencatat hasil kerja klasifikasi [13]. Evaluasi performasi dilakukan untuk menguji hasil dari klasifikasi dengan mengukur nilai performasi dari model yang telah dibuat. Parameter pengujian yang digunakan untuk evaluasi yaitu akurasi yang perhitungannya diperoleh dari tabel Confussion Matrix.

Tabel 1. Confussion Matrix

\begin{tabular}{|l|c|c|c|}
\hline & True Negatif & True Positif & True Netral \\
\hline Pred.Positif & FN & TP & Fnet \\
\hline Pred.Netral & FN & FP & Tnet \\
\hline Pred. Negatif & TN & FP & Fnet \\
\hline
\end{tabular}

Nilai akurasi menunjukan ketepatan hasil proses klasifikasi data secara benar. Dapat dikatakan nilai akurasi merupakan perbandingan data yang terklasifikasi benar terhadap keseluruhan data. Nilai akurasi dihitung dengan persamaan berikut.

$$
\text { Accuracy }=\frac{T P+T N+\text { Tnet }}{T P+T N+F P+F N+F N e t+\text { Tnet. }}
$$

\section{HASIL DAN PEMBAHASAN}

Penelitian dilakukan dengan kombinasi metode atau melakukan penentuan jumlah fitur pada proses seleksi fitur. Tujuan dari proses seleksi fitur ini agar semakin sedikit jumlah fitur yang digunakan, semakin rendah waktu komputasi dan semakin tinggi akurasi yang dicapai. Tahap seleksi fitur akan membandingkan seleksi fitur menggunakan $\mathrm{Chi}$ Squared Statistic dan Particle Swarm Optimization (PSO).

\subsection{Persiapan Dataset}

Twitter menyediakan data yang bisa diakses secara bebas dengan menggunakan Twitter API (Application Programming Interface) [14]. Tahap crawling mengambil data tweets yang mengandung 5 (lima) kata kunci, yaitu "Vaksin Sinovac", "Vaksin Astrazeneca", "Vaksin Moderna", "Vaksin Merah Putih", dan "Vaksinasi Covid-19". Dengan proses crawling didapatkan dataset tweets dari tanggal 4 Agustus 2021 sampai 12 Agustus 2021 yang ditunjukan pada tabel berikut.

Tabel 1. Total Dataset Hasil Crawling Tweets

\begin{tabular}{|c|l|c|}
\hline No. & \multicolumn{1}{|c|}{ Kata Kunci } & Jumlah Records \\
\hline 1 & Vaksin Sinovac & 449 \\
\hline 2 & Vaksin Astrazeneca & 465 \\
\hline 3 & Vaksin Moderna & 351 \\
\hline 4 & Vaksin Merah Putih & 152 \\
\hline 5 & Vaksinasi Covid-19 & 643 \\
\hline \multicolumn{2}{|c|}{ Total } & $\mathbf{2 0 6 0}$ \\
\hline
\end{tabular}

Data tweets selanjutnya diberi label secara manual ke dalam tiga kategori, yaitu kategori positif, netral, dan negatif. Data tweets disimpan dalam file excel yang terdiri dari 1193 positif, 73 negatif dan 794 netral.

\subsection{Seleksi Fitur Chi-Squared Statistic}

Tahap seleksi fitur menggunakan Chi Squared Statistic dilakukan dengan optimize selection. Pada optimize selection digunakan 
parameter forward selection. Hasil seleksi fitur ini mendapatkan 24 kata terseleksi.

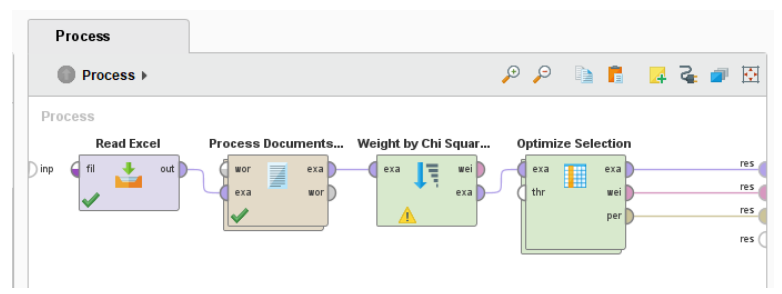

Gambar 5. Proses Seleksi Fitur Chi-Squared Statistic

\subsection{Seleksi Fitur Particle Swarm Optimization}

Optimize weights PSO sebagai seleksi fitur dengan parameter forward selection dapat dilihat pada gambar berikut.

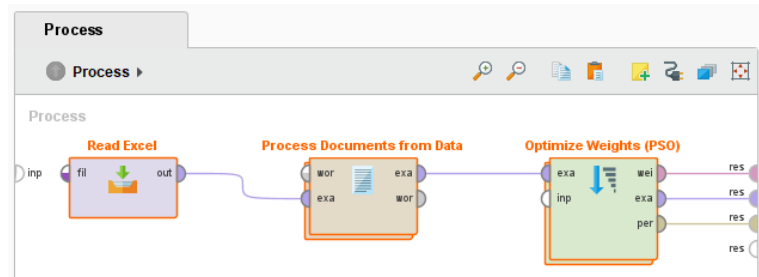

Gambar 6. Proses Seleksi Fitur Optimize weights PSO

Hasil seleksi fitur PSO dengan parameter Term Frequency didapatkan 28 kata yang terseleksi.

\subsection{Hasil Pengujian dengan Naive Bayes \\ Classifier}

Pengujian pertama dilakukan untuk mengetahui tingkat akurasi dari penggunaan algoritma Naive Bayes Classifier tanpa seleksi fitur. Desain proses untuk pengujian klasifikasi dengan Naive Bayes Classifier dapat dilihat pada gambar berikut.

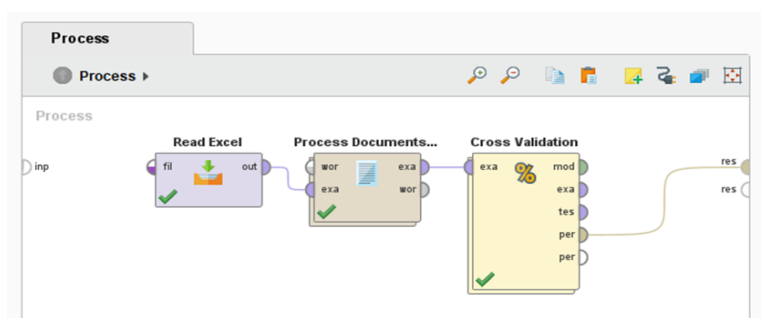

Gambar 7. Proses Pengujian Klasifikasi dengan NBC

Cross validation membagi data menjadi 10 bagian sama banyak, satu subset untuk data pelatihan dan subset lainnya untuk data pengujian. Hasil evaluasi pengujian dengan
Confussion Matrix pada algoritma Naive Bayes Classifier di atas ditunjukan pada table berikut.

Tabel 2. Confussion Matrix pada Algoritma NBC

\begin{tabular}{|l|c|c|c|c|}
\hline & $\begin{array}{c}\text { true } \\
\text { Negatif }\end{array}$ & $\begin{array}{c}\text { true } \\
\text { Positif }\end{array}$ & $\begin{array}{c}\text { true } \\
\text { Netral }\end{array}$ & $\begin{array}{c}\text { Class } \\
\text { precision }\end{array}$ \\
\hline Pred.Positif & 334 & 465 & 33 & $55,89 \%$ \\
\hline Pred. Netral & 31 & 100 & 19 & $12,67 \%$ \\
\hline Pred. Negatif & 828 & 229 & 21 & $76,81 \%$ \\
\hline class recall & $69,40 \%$ & $58,56 \%$ & $26,03 \%$ & \\
\hline
\end{tabular}

Tabel 2 menunjukan bahwa penggunaan algoritma Naive Bayes Classifier tanpa seleksi fitur mendapat nilai akurasi $63,69 \%$.

\subsection{Hasil Pengujian Chi-Squared Statistic dengan Naive Bayes Classifier}

Pengujian kedua dilakukan untuk mengetahui tingkat akurasi algoritma Naive Bayes Classifier dengan penggunaan seleksi fitur Chi-Squared Statistic berbasis forward selection.

Tabel 3. Confussion Matrix Chi-Squared Statistic Berbasis Forward Selection pada Algoritma NBC

\begin{tabular}{|l|c|c|c|c|}
\hline & $\begin{array}{c}\text { true } \\
\text { Negatif }\end{array}$ & $\begin{array}{c}\text { true } \\
\text { Positif }\end{array}$ & $\begin{array}{c}\text { true } \\
\text { Netral }\end{array}$ & $\begin{array}{c}\text { Class } \\
\text { precision }\end{array}$ \\
\hline Pred.Positif & 372 & 603 & 39 & $59,47 \%$ \\
\hline Pred. Netral & 4 & 3 & 4 & $36,36 \%$ \\
\hline Pred. Negatif & 817 & 188 & 30 & $78,94 \%$ \\
\hline class recall & $68,48 \%$ & $75,94 \%$ & $5,48 \%$ & \\
\hline
\end{tabular}

Tabel 3 menunjukan bahwa penggunaan seleksi fitur Chi-Squared Statistic berbasis forward selection mampu meningkatkan akurasi Naive Bayes Classifier hingga mencapai 69,13\%.

\subsection{Hasil Pengujian PSO dengan Naive Bayes Classifier}

Pengujian ketiga dilakukan untuk mengetahui tingkat akurasi algoritma Naive Bayes Classifier denga seleksi fitur PSO menggunakan parameter Term Frequency (TF).

Tabel 4. Confussion Matrix PSO Menggunakan Parameter TF pada NBC

\begin{tabular}{|l|c|c|c|c|}
\hline & $\begin{array}{c}\text { true } \\
\text { Negatif }\end{array}$ & $\begin{array}{c}\text { true } \\
\text { Positif }\end{array}$ & $\begin{array}{c}\text { true } \\
\text { Netral }\end{array}$ & $\begin{array}{c}\text { Class } \\
\text { precision }\end{array}$ \\
\hline Pred.Positif & 223 & 417 & 31 & $62,15 \%$ \\
\hline
\end{tabular}




\begin{tabular}{|l|c|c|c|c|}
\hline Pred.Netral & 48 & 115 & 21 & $11,41 \%$ \\
\hline Pred. Negatif & 922 & 262 & 21 & $76,51 \%$ \\
\hline class recall & $77,28 \%$ & $52,52 \%$ & $28,71 \%$ & \\
\hline
\end{tabular}

Tabel 4 menunjukan bahwa PSO dengan parameter Term Frequency (TF) meningkatkan akurasi algoritma Naive Bayes Classifier hingga mencapai $66,02 \%$.

Confusion matrix pada tabel 5 menunjukan bahwa pengujian yang dilakukan dapat meningkatkan akurasi algoritma Naive Bayes Classifier. Komparasi seleksi fitur Chi Squared Statistic dan Particle Swarm Optimization (PSO) dengan Naive Bayes Classifier dapat dilihat pada tabel 5.

Tabel 5. Komparasi Akurasi Chi-Squared Statistic dan Particle Swarm Optimization pada Algoritma NBC

\begin{tabular}{|l|c|}
\hline \multicolumn{1}{|c|}{ Komparasi } & Accuracy \\
\hline Algoritma NBC & $63,69 \%$ \\
\hline $\begin{array}{l}\text { Chi-Squared Statistic berbasis Forward } \\
\text { Selection pada Algoritma NBC }\end{array}$ & $69,13 \%$ \\
\hline $\begin{array}{l}\text { PSO dengan parameter Term Frequency } \\
\text { (TF) pada Algoritma NBC }\end{array}$ & $66,02 \%$ \\
\hline
\end{tabular}

Hasil pengujian seleksi fitur Chi-Squared Statistic dan Particle Swarm Optimization (PSO), keduanya terbukti mampu meningkatkan nilai akurasi algoritma Naive Bayes Classifier. Pengujian algoritma Naive Bayes Classifier menggunakan seleksi fitur Chi-Squared Statistic berbasis forward selection memiliki nilai akurasi yang lebih tinggi yaitu $69,13 \%$, dibandingkan dengan seleksi fitur Particle Swarm Optimization (PSO) dengan parameter term frequency (TF) sebesar 66,02\% dengan selisih akurasi sebesar 3,11\%.

\section{KESIMPULAN}

Simpulan yang dapat diambil dari penelitian ini adalah:

1. Proses seleksi fitur chi squared statistic dan particle swarm optimization (PSO) yang digunakan dalam penelitian ini terbukti mampu menyeleksi jumlah term menjadi lebih sedikit sehingga mempermudah proses seleksi klasifikasi naive bayes menjadi lebih cepat.
2. Hasil Pengujian algoritma Naive Bayes Classifier menggunakan seleksi fitur Chi Squared Statistic berbasis forward selection memiliki nilai akurasi yang lebih tinggi dibandingkan menggunakan seleksi fitur Particle Swarm Optimization (PSO) dengan parameter term frequency (TF) dengan selisih akurasi sebesar 3,11\%.

\section{DAFTAR PUSTAKA}

[1] H. Noviyani, . A. Y. Permana and A. Fauzi, "Komparasi Algoritma Nä̈ve Bayes Dan K-Nearest Neighbor Dalam Melihat Analisis Sentimen Terhadap Vaksinasi Covid-19," Jurnal Ilmiah Informatika, Arsitektur dan Lingkungan, vol. 14, no. 1, 2021.

[2] M. Al-Ayyoub, A. A. Khamaiseh, Y. Jararweh and M. N. Al-Kabi, "A Comprehensive Survey Of Arabic Sentiment Analysis," Information Processing and Management, vol. 56, no. 2, pp. 320-342, 2019.

[3] J. Ling, I. P. E. N. Kencana and T. B. Oka, "Analisis Sentimen Menggunakan Metode Nä̈ve Bayes Classifier dengan Seleksi Fitur Chi Square," E-Jurnal Matematika, vol. 3, no. 3, pp. 92-99, 2014.

[4] Y. Cahyono, "Analisis Sentiment pada Sosial Media Twitter Menggunakan Nä̈ve Bayes Classifier dengan Feature Selection Particle Swarm Optimization dan Term Frequency," Jurnal Informatika Universitas Pamulang, vol. 2, no. 1, pp. 14-19, 2017.

[5] P. Routray, C. K. Swain and S. P. Mishra, "A Survey on Sentiment Analysis," International Journal of Computer Applications, vol. 76, no. 10, pp. 1-8, 2013.

[6] Ratino, N. Hafidz, S. Anggraeni and W. Gata, "Sentimen Analisis Informasi Covid-19 menggunakan Support Vector Machine dan Nä̈ve Bayes," Jurnal JUPITER, vol. 12, no. 2, pp. 1-11, 2020.

[7] B. Laurensz and E. Sediyono, "Analisis Sentimen Masyarakat terhadap Tindakan Vaksinasi dalam Upaya Mengatasi Pandemi Covid-19," Jurnal Nasional Teknik Elektro dan Teknologi Informasi, vol. 10, no. 2, pp. 118-123, 2021.

[8] N. P. G. Naraswati, D. C. Rosmilda, D. Desinta, F. Khairi, R. Damaiyanti and R. Nooraeni, "Analisis Sentimen Publik dari Twitter Tentang Kebijakan Penanganan Covid-19 di Indonesia dengan Naive Bayes Classification," Jurnal Sistem Informasi, vol. 10, no. 1, pp. 222-238, 2021. 
Ristasari Dwi Septiana, Agung Budi Susanto, Tukiyat

[9] X. Hu, R. C. Eberhart and Y. Shi, "Particle Swarm with Extended Memory for Multiobjective Optimization," in IEEE Swarm Intelligence Symposium, 2003.

[10] R. Feldman and J. Sanger, "The text mining handbook: advanced approaches in analyzing unstructured data," Cambridge university press, 2007.

[11] M. Arhami and M. Nasir, Data Mining Algoritma dan Implementasi, vol. 6, R. I. Utami, Ed., Lhokseumawe, Buketrata: Penerbit ANDI, 2020, pp. 104-111.

[12] Rinawati, "Penerapan Particle Swarm Optimization Untuk Seleksi Atribut pada Metode Support Vector Machine untuk Penentuan Penilaian Kredit," in Seminar Nasional Ilmu Pengetahuan dan Teknologi Komputer (SNIPTEK), Jakarta, 2013.

[13] E. Prasetyo, Data Mining Konsep dan Aplikasi menggunakan MATLAB, Yogyakarta: CV. Andi Offset, 2012.

[14] E. S. Negara, R. Andryani and P. H. Saksono, "Analisis Data Twitter: Ekstraksi dan Analisis Data Geospasial," INKOM, vol. 10, no. 1, pp. 27-36, 2016. 